\title{
Correction to: Economic growth, energy consumption, and environmental quality nexus in Turkey: Evidence from simultaneous equation models
}

\author{
Mushtaq Ahmad Malik ${ }^{1}$ iD \\ Published online: 24 April 2021 \\ (C) Springer-Verlag GmbH Germany, part of Springer Nature 2021
}

Correction to: Environmental Science and Pollution Research https://doi.org/10.1007/s11356-021-13468-7

The published paper contains misplaced table footnotes in the text.

The original article has been corrected.

Publisher's note Springer Nature remains neutral with regard to jurisdictional claims in published maps and institutional affiliations.

The online version of the original article can be found at https://oi.org/ 10.1007/s11356-021-13468-7

\footnotetext{
Mushtaq Ahmad Malik

malikmushtaq10@gmail.com

1 Department of West Asian and North African Studies, Aligarh Muslim University, Aligarh, India
} 